\title{
Why would you buy an electric car on Jetski Friday? Or, a critique of financial markets from an options trading room
}

\author{
Daniel Soueles \\ Copenhagen Business School, Denmark
}

\begin{abstract}
This article presents a close, dialogue-based ethnographic account of a group of contemporary options market makers making a decision about pricing options in Tesla, Inc. Careful attention to their deliberations reveals how the rise of algorithms and automation on financial markets have rendered traders alienated and estranged from the markets they work on for their livelihood. This alienation arises, in part, due to novel cascade effects between futures and underlying equities, which algorithmic and automated trading seems to afford, and which also relate to news events as well as the actions of politicians and prominent business people. Emerging from this alienation, traders produce a critique of how highly automated financial markets allocate capital and how ripe they are for political manipulation.
\end{abstract}

\section{Keywords}

Finance, markets, alienation, options, trading

\section{What should we buy this Friday?}

As odd as the title of this article sounds, I think it's worth dwelling on as a starting point for just how difficult it is for some professional traders, as of Spring 2019, to allocate wealth on capital markets and the frayed connections between many finance people and the markets they work. I heard it was a good idea to buy an electric car on Jetski Friday when I spent four weeks as a sort of stenographer-in-residence with a group of seven options market-makers, at a U.S.A.-based proprietary trading firm ('TradeCo') in February and again in May (two weeks in each) of 2019. These observations were part of a larger, multi-year group project on computerized stock trading that has seen me and a team of colleagues conduct 184 interviews (of which I did 69) in various financial hubs (mostly Chicago, New York, London, and

\section{Corresponding author:}

Daniel Souleles, Copenhagen Business School, Porcelænshaven 18A, 2.132, 2000 Frederiksberg, Denmark.

Email: ds.mpp@cbs.dk. https://doi.org/10.2218/finsoc.v7i2.6628 
Amsterdam) with market participants, regulators, exchanges, and portfolio managers, visit a number of other trading firms, attend industry events, and construct an agent-based modeling platform to simulate market outcomes with a variety of trading-agent ecologies, all to understand why and how financial markets have changed due to the rise of algorithmic, automated trading. This sort of composite approach to fieldwork is fairly typical when studying financiers and other hard-to-access folks (e.g., Souleles, 2018).

For nine to ten hours per day I would watch Jeff Miller and his team of six other male traders sit in a horse-shoe shaped chain of desks, reclining in over-stuffed, wheeled office chairs, seated, backs to each other, in front of stacks of monitors on height-adjustable desks, surrounded by the detritus of take-out meals. I would watch them price options, tend to their trading positions, monitor market feeds, argue about the positions they would take, develop code, as well as pass the time by eating, chatting, gambling, debating, joking, watching sports, watching game shows, watching financial news or yelling at a radio news feed that never seemed to say anything useful. All told, my observations generated about 1,000 pages of mostly dialogue-based field notes.

My method was to sit for the full working day and try to type everything that everyone said, as well as to note things going on in the trading room - people coming and going, what was on TV, what people were eating and drinking, what people were wearing, how people were physically interacting, etc. Unlike more active forms of participant observation, there wasn't really any way I could take part in their market making; and I don't think there was any universe in which the team was going to let me make bets on their account. So, I just soaked it all up and typed until my fingers went numb (see Spradley, 1980 for a typology of observation work in anthropology; see Souleles n.d. for a further explanation of how I analyzed my notes from the trading room). Too, part of the reason I was able to get so much out of my month with Jeff and his team, was because my observational work fit into the larger context of our project's interview and simulation work. In a way, my watching them allowed me to triangulate findings from other parts of our multi-year project (e.g., Denzin, 1970: 297-314).

As near as I could tell, over the month that I was there, Jeff and his team didn't act or trade any differently while I sat with them. They mostly ignored me but would occasionally chat or joke with me. A few times they wryly suggested that I might secretly be a regulator; and a few other times they would emphasize something they said as particularly important and would make sure I wrote it down. But mostly I just sat there typing while they did their job. It's worth noting, too, that people, particularly when excited, could talk a bit faster than I could type, so sometimes I was reduced to a bit of shorthand. That said, I stand behind the record I kept, particularly as it relates to the interactional dynamics between traders, which is much of what this article turns on.

The electric car in this article's title is a 'Tesla', which exists at several models and price points, and is in turn made by (and, here, a stand-in for) the U.S.-based, publicly-listed 'Tesla Inc.,' a company led by celebrity-C.E.O. Elon Musk and dedicated to, in its own words, "accelerat[ing] the world's transition to sustainable energy" (Tesla, 2019).

Whether or not someone would be willing to buy Tesla stock in turn affects that stock's price, which affects the ability of Tesla Inc. to raise money to finance its operations, invest in manufacturing capacity, pay workers or keep the Elon Musk show going. Tesla's financing via capital markets, in turn, is a good place to start with Jeff and his team's difficulties. What I will suggest is occurring when Jeff and his team price Tesla stock and options as 'market-makers' is that they are trying to act on their views of how investment-worthy Tesla is via financial markets. This action, too, is informed by how Jeff and his team understand current opportunities on financial markets generally. 
Very basically, I suggest that Jeff and his team have a frayed, unreliable relationship with the markets they trade on, and the larger ambient market environment they rely on. Illustrating the misfit between the traders' sense of a company and the market it trades on versus how that market and company actually behave will go some way to show what it feels like to be a trader caught up in larger processes of market automation and attendant workplace alienation. In a Marxist sense, alienation and estrangement happen when the product of a laborer's work is not their own, or when a worker's labor time is not their own, or when a given productive process reduces human participation to insignificance as tends to happen as capitalism develops (Benanav, 2020; Marx, 1978; Weiss, 2021). One way to understand the spread of automation in finance is that it dramatically increases the productivity of the whole financial system (e.g. exponentially more transactions) against an ever proportionally diminishing number of traders (see Benanav, 2020). The traders who remain to trade in person, trade ever smaller portions of markets while the traders who remain to supervise and tinker with algorithms have less and less control over what algorithms do and how markets develop, particularly once algorithms interact with each other and create all manner of feedback loops.

Much of what the following ethnographic account will show is an example of how trading actually works and what trading actually feels like given the increasing estrangement and alienation of traders from markets. Contrary to other accounts of traders that see them as heroic, or exceptionally competent market actors, the present state of market structure and government fuelled financialization can also leave professional traders with a limited scope of action on the markets they work on as well as a lot to complain about. Some academic background will help develop this line of argument.

\section{A short state of the art}

Over the last few decades, as financial markets have electrified and automated (e.g., Pardo Guerra, 2019), scholars have suggested that traders have capably adapted to the rise of screen-based (Beunza and Stark, 2012) or even automated trading (MacKenzie, 2021). A number of scholars have offered close empirical work to show that as trading electrified, automated, and got off the trading floors, cognition shifted and sometimes expanded via systems designed for computer-mediated market surveillance, access, and action (Beunza and Stark, 2004; Cetina and Bruegger, 2002; Cetina and Preda, 2007). The sense that comes out of this body of literature is that despite dramatic shifts in technological affordances on financial markets, the essential core of norms and social networks that Abolafia (2001) saw as being so vital to market behavior in the 1990s basically still exists and allows traders to ply their expertise and profit from markets.

Along with accounts of this expanded capacity for market knowledge and action, scholars have also suggested a countervailing narrative, one in which novel and specific forms of ignorance, which have arisen due to changes in market technologies and infrastructure, make it difficult to understand other market actors or even action in one's own firm (Hansen and Borch, 2021; Lange, 2016; Lange, Lenglet and Seyfert, 2019; Souleles, 2019b; Zaloom, 2006). 1 Much of this research, particularly the more recent contributions to it, has paid close attention to the algorithms, programmers, and machine systems that make contemporary market environments often inscrutable and difficult to navigate. Here, in thinking about Jeff, his traders, and Tesla, I would like to build on these studies of limitation and ignorance, which I find accurate in conveying how uncertain it feels like to be a trader. Moreover, I would like to add to this record a slightly more holistic account of these limitations. After all, and as we'll 
see, it's not just computers and algorithms that are confounding or limiting but rather the larger market and political environment that such technology affords. Taken together, this makes it increasingly difficult, and perhaps futile, for the traders I studied to accurately price or even understand the securities for which they are market makers.

So, for traders, as Jeff and co. call themselves, buying an electric car would mean the evaluation of the stock's price and making some sort of judgment about how investors will trade it, as well as what demand for options that trading will generate. An option is just a sort of contract allowing you to buy or sell a particular stock at a set price by a set date, making for a type of insurance (or speculative tool) (MacKenzie, 2008: 119-211; McMillan, 2002). And a market maker is a specialized kind of trader that makes money by always being willing to buy and/or sell financial instruments, profiting by providing a market function as opposed to making directional investments - a classic market 'middleman'. Market makers are not investing, per se, but pricing spreads of options, and making money from being on both sides, long and short, of that liquidity-providing enterprise. So far so good. But, how does this sort of pricing fit into a larger financial ecosystem? What does it rely on and relate to? After all, providing a basic middleman function could be seen as a relatively neutral, benign, and reliable way to be on markets. What about the Jetskis?

The problem with stock, or options, or futures trading - really any sort of financial transaction - is that markets are incredibly and increasingly complicated. There are lots of different types of traders acting over varied time horizons, all with any number of strategies motivating what they are buying and selling, all in a government-regulated environment that spans numerous trading venues and exchanges, many of which sell the same products. Moreover, and again, market participants are mostly and increasingly automated and anonymous from and to each other (e.g. Souleles, 2019b), which turn the interactional dynamics between participants into highly speculative and often largely automated affairs. Someone may make a long-term Tesla play because they like the company and think that its battery business will be increasingly indispensable to a global fleet of electric vehicles and decentralized power grids over the next decade. Someone else might be short-selling the stock because they think Elon Musk is an erratic megalomaniac who will drive his company into the ground due to a fight with America's financial regulators. Still another trader might simply be a market-making algorithm deployed by a massive hedge fund, treating Tesla as any other generic, fungible stock, buying and selling at the same time, perhaps ensuring liquidity, or at least churn, on a market. Beyond these strategies are larger geopolitical considerations. If China carries on subsidizing the domestic development of high-capacity batteries, one might persuasively argue that Tesla is vulnerable to competition. However, if California or Norway continue to offer a tax break for purchasers of electric vehicles, perhaps we can forgive Mr. Musk some of his perceived sins.

Even beyond the gyrations of an individual stock, certain politicians act as though the aggregate performance of American equity markets has become coterminous with the economic health of the nation and the success of particular presidential administrations. Given that, indications of ill health across financial markets - say, drops perceived as too rapid, prices behaving with too much volatility, or even a lack of activity altogether - often may kick national industrial or financial policy into action. One president may rashly declare a trade war or tweet about intending to lift tariffs. Another might propose a Keynesian stimulus plan. Or an agent of the central bank may seek to calm markets by fiddling with interest rates, buying up bad investments from banks as in 'Quantitative Easing' or 'QE' or even simply using public persuasion. The goal of all of this is to indirectly protect the nation's economic health via shifting the baseline inputs and assumptions that investors and traders take with them to 
market. The traders I sat with had noticed this sort of government action as one more market feature they were trying to figure out, often operating according to a different scalar logic than the behavior of any particular stock. The fact that there is a difference between politicians treating markets as total entities and traders like Jeff and his team seeing just individual stocks ('names' as they called them) and other individual traders, affected how and whether a company like Tesla and a CEO like Musk could get money from financial markets.

What made this high-level political action particularly salient for the traders I was sitting with was the fact that markets seemed to be digesting politics as well as news in a fundamentally different way than in decades past, largely due to automated cascade effects that they only partially understood. It seemed that any time a politician spoke on the economy, about markets, about interest rates or regarding a trade war, there would be a near instantaneous market response, starting in S and P 500 index futures (contracts to buy big bundles of stock at some point in the future), which would then lead to a rally or a fall in the given stocks promised in a future contract. Within an hour or two of announcements or news (or announcements of future potential news), a market swing accounting for ups of 2 percent could have happened. Moreover, there seemed to be a cumulative upward bias to these swings, sending equities and all related instruments ever higher with surprisingly little volatility (gyrations or variability in price; see Wigglesworth, 2019).

Jeff and his team had a poor understanding of the exact agents and relationships kicking off this cascade as well as of the mechanism by which futures and indices shaped equities as quickly as they did. After all, shouldn't a stock price be antecedent to some future contract based on that stock? The actors purchasing these futures could be anyone from hedge funds with 'event-driven' trading strategies to central banks and automated trading agents trained to instantly respond to the news. ${ }^{2}$ In any event, as aggregate entities, markets seemed to respond drastically, quickly, and in lockstep to politics and news, with some manner of a longterm, upward bias. Moreover, the traders felt that these aggregate swings had little to do with the fundamental economic reality of the specific equities and options available for the specific companies they traded.

This disconnect was expressed through a humorous type of fatalism that suggested they were on the wrong side of a larger historical trajectory in how markets behaved and how they were governed. The traders, as noted above, are professional financial analysts. They can price options, sense a good bet, and make sophisticated arguments about the behavior of companies well into the future. They're also pretty savvy (though unhappy) readers of markets in aggregate, and feel they're fairly good at guessing the motivation, or at least the actions, of the people they're opposite to in the electronic order book. Moreover, they've profitably outlasted numerous other trading groups in their own firm that have come and gone. That said, large macroeconomic policy interventions around things like interest rates or trade wars, seemed, to them, decoupled from all fundamental market action, more often than not, due to the whims of fickle or feckless political actors.

They joked that if markets were down, you could expect to see someone from the U.S. central bank (the Federal Reserve), or the treasury department, usually on a Friday, show up on the news, offering the sort of vaguely positive assurance that would lead to a cascade, and a one or two percent rally, sending markets back up, despite any individual, company-based fundamental analysis that Jeff and the team had done. They came to call these Fridays when markets would irrationally go up and politicians could ensure that every American could exercise their God-given, inalienable right to buy something as useless and expensive as a Jetski with the profit from their privatized, stock-based retirement accounts, 'Jetski Fridays'. 
The subtext of this joke was that whereas politicians are treating markets as aggregate entities that generate wealth for retirees and indicate national strength, Jeff and his team see markets as being made up of individual stock and companies and other market participants arrayed to judiciously allocate capital to deserving enterprises. But there are also other, larger political subtexts to the resignation and frustration felt in this joke: if one sees a market as an aggregate phenomenon related to national strength, of course it ought to only go up. However, if a market is actually just a lot of individual companies and traders competing with one another for wealth, then it's reasonable to assume that stock prices can (and sometimes should) go down.

All these overlapping interests and frustrated feelings resulted in, of all things, some office swag. The traders had a set of grey cotton t-shirts with a green 'Jetski Friday est. 2009' logo and a silhouette of a Jetski rider tearing through a wave made, and would wear them on Fridays. They even gave me one. The joke was that market weirdness and America's promise were both born in a placid, steadily rising stock market, and that promise, in turn, was cashed in at your local Kawasaki dealership. If a politician had worked markets to the point that an individual had enough money in their stock-based retirement account, that retiree could then sell their shares and buy their own Jetski, their own slice of the American dream. In this scenario stock prices inflate forever and a reckoning never seems to come to the companies that Jeff and his team think are bad actors in need of market discipline. All that's left to do is make some swag and watch it all unwind.

To recapitulate, the t-shirts circulating in TradeCo's office encapsulated much of what I'm suggesting is new about present-day markets and the traders trying to make sense of them. Specifically, rather than markets just being a technological precipitate of evolving computer systems - with algorithmic ignorance built in to markets and their participants, interested parties seem to be using the novel technological affordances of algorithmic automation to digest political news quickly and establish correlations between futures and underlying stock that seem decoupled from any specific company's health or even aggregate market fundamentals. Also taking advantage of this dynamic is an often peculiar mix of institutional investors, such as pension funds, politicians, and celebrity CEOs, like Elon Musk. All this makes for an alienating environment (but some good t-shirts), if you feel financial markets should be company-specific capital allocators.

Now, to the particulars of Jeff and the team's trading activities.

\section{You guys don't do this at work?}

The best way to get to know Jeff and his team is to listen to them. Though they mostly sit in front of screens all day, they narrate to each other, more or less constantly, what they're doing, what they're seeing, and how they feel about all of it. Linguist Koenrad Kuiper (1996) has profitably distinguished two registers of speech (as in Agha, 2000, 2015) among professional fast talkers (auctioneers and sportscasters): first, observational 'play-by-play' ways of talking, and second, analytic 'commentary' ways of talking. Listening to Jeff's team, we'll hear them shift back and forth between both registers, often allowing the play-by-play to tacitly argue for whatever commentary or analysis an individual is offering (see similarly Beunza, 2019: 61-63, drawing on, e.g., Heath et al., 1994; Hutchins, 1995).

Here then is an example of talk that will relate the flavour of a typical day. Note that cross talk from six to eight people who know each other well and who all have extremely long working relationships with each other can sound clipped and fragmentary to an outsider. As such, I've reduced the number of turns present and condensed diffuse utterances into specific 
turns. I've also extended some clipped utterances into sentences to help the transition of spoken language into written record. Too, one shouldn't worry that much about the jargon Jeff and his team use (their professional jargon is dense and confusing to non-finance people). Rather, try to see how they bounce off of each other when narrating (play-by-play) and arguing (commenting) what is happening on financial markets and what they should do.

To set the scene, the traders are sitting in their horseshoe, at their workstations, in front of their stacked monitors. The large TV on the wall is tuned away from financial news over to the American game show, The Price Is Right.

Tony Ellis: Apple vol is having a big uptick [vol is short for 'volatility' or the amount some financial instrument's price moves around].

Brandon Price: I can't stop buying this vxx [vxx is a financial product based on a measure of aggregate market volatility, the 'VIX' index]. I really don't even understand how we do these trades. Fuck, I knew I should've sold it.

Jeff Miller: Look at this guy go crazy. Another new car. This guy looks like he's going to die. What, you guys don't watch this at work?

Dan Souleles: I wish we did.

Everyone: A NEW CAR!

Trader from another group: You guys are watching The Price Is Right?

Jeff: Yeah, Brandon is in a really bad mood, so he put The Price Is Right on.

Trader: Well, that helps.

Rob Ortiz: At least someone is making money.

Tony: You guys actually think we could have a big down day?

All told, this is less than thirty seconds of dialogue, amounting to less than a half-page out of the hundreds of pages and notes I recorded. And even during this brief time we have amassed observations about a large number of market relationships: about automated trades happening and perhaps getting away from their intended targets, complaints that the traders are getting into bad trades of different types of financial instruments, a game show put on to pass the time and take minds off bad trades, a joke about one trader's pitiful day, and speculation regarding the direction of the whole portfolio. Moreover, you get to hear the head of the trading team joke with me while someone else from another trading team checks in with the group I am observing.

At Tradeco, topics don't tend to be discrete. People bounce from subject to subject, often picking up threads after having dropped them seconds, minutes, and hours before; folks feel comfortable expressing themselves; and it all weaves into a long dialogue. It was in this sort of setting that an argument about Tesla came up. Jeff Miller, the group leader, was bothered by how Tesla's stock wasn't doing what he thought it should and was looking for some validation, an argument or just something from the rest of the team. A fair portion of the work that folks at Tradeco do is pricing in unusual events during their market-making activity. Put another way, they are trying to understand abnormal risk, price it, and market-make accordingly. Tesla was just one of 40 to 60 stock names they priced, traded, and followed. 
The conversation all starts with Walt Bennett the supervising partner of this office asking Jeff how the day was going. Again, the language is fairly technical. Given that, it's worth paying more attention to how the observational bits of the conversation allow Jeff to make an argument about taking a position with Tesla.

Jeff Miller: I'm going down to the floor for a minute. There isn't much grind up here. There is some bad news on Apple, but it doesn't matter. Their China sales are a big, big miss.

Walt Bennett: What about Tesla? When does that convertible bond come due?

Jeff: March 1st.

Walt: What do the vols look like?

Tony Ellis: They're in the mid to upper fifties.

Jeff: I thought it was lower than that, low 40s.

Walt: What about one year out, are they in the same place?

Tony: The put skews are very high compared to other symbols we follow.

Jeff: The twenty-strike-put expires in twelve months. The ten put is 50 cent, which doesn't get much better. Hundreds are twelve fifty. Your payoff on that is terrible 12 months off.

Walt: I'm thinking of buying 280s.

Jeff and Tony: They're much better.

Jeff: Well, I'm ready to pack it in. We've been carrying twelve hundred vegas, nothing big. ${ }^{3}$ Some unknown firm upgraded Tesla and they're up like 8 dollars.

Tesla just doesn't trade like a real symbol. There is so much flow controlled by only a handful of people. It just doesn't - it isn't affected by news. Tesla can miss bond payments and it just doesn't matter. Someday it will.

Walt, Jeff and Tony are talking about Tesla puts being high, that is, a lot of people are buying put options ('put' options are the option to sell a stock at a specific price by a particular date; 'call' options are the opportunity to buy stock at a specific price by a specific date). The assumption here is that a lot of people think that Tesla's stock will go down. If the stock goes down, having the ability to sell the stock at a higher price would make an investor a lot of money. In a more limited way, an options market-maker would have the ability to price and then sell lots of puts at a premium.

While I was in Hub City, Tesla was trading in the ballpark of US\$300 per share. If the stock went all the way to zero, owning a lot of US $\$ 280$ put options would make you a lot of money. Tesla was actually down for much of the middle of 2019 following my two visits, and Tradeco's short bets presumably made a lot of money over that time. However, as Jeff points out, evaluating whether Tesla is going to zero at any given time is a tricky business.

Jeff's thesis and frustration are pretty simple: Tesla doesn't trade like a normal stock. Bad news comes out and it doesn't matter. It can miss payments or shipping targets, have terrible news about the company or the CEO, and the price doesn't change. Jeff suggests that only a few people control the order flow of the company's stock. None of it makes sense. The 
thing, too, is at the time, Jeff was right about basically everything: Operationally, Tesla has had chronic issues meeting its own production and distribution targets and had recently announced that it would be closing all of its brick-and-mortar stores (Harwell, 2019a). Managerially, Tesla's CEO, Elon Musk, is in an ongoing legal dispute with America's stock regulator, the Security and Exchange Commission, because the SEC maintains that Musk was improperly influencing the price of the stock by tweeting information about the company's production figures and potential future buyout by an investment fund. As of this writing, there is a chance that Musk may actually be held in contempt of court (Harwell, 2019b). Jeff and Walt both mention a big debt payment that was coming due.

While I was doing fieldwork, Jeff speculated that Tesla wouldn't be able to make that payment. ${ }^{4}$ And for all this, at the time at least, Tesla stock seemed to just go up. Elon Musk just got richer. It just became easier for Tesla to make money. Retirees had more money in their stock accounts. And the folks like Jeff who wanted Tesla to pay for its perceived bad actions continued to lose money.

They continue talking:

Walt: Yeah, that's my thinking too. Someday - well, it can't levitate indefinitely. That name will explode. I just don't know when.

Jeff: How about that Wall Street Journal article about the service problems they're having?

Tony: They cut half their delivery guys.

Walt: Their staff to deliver cars, they cut them in half?

Jeff: This article is about service. If you nick your bumper it takes four months to get fixed. They have no repair apparatus or spare parts.

Granular short players have been talking about this for a while. ${ }^{5}$ When a company like BMW gives you a car and three years of service, they put that on their balance sheet. Tesla isn't doing that. They're counting the parts and the repair as CAP X.

Walt: CAP X?

Jeff: That's the allegation of the short players: Tesla's accounting guys are really fucking around with service plan liabilities. But it seems like none of it matters. Someday it will. Anyway, not a lot of news today.

Walt: See you at lunch time.

Beyond the general issues with Tesla that we heard about above, Jeff is zeroing in on a few specifics of Tesla's practices. First, he's noting that they have some large functional issues: namely a huge backlog of repairs and a lack of parts to make fixes. Beyond this, whereas most car firms book this sort of maintenance in a straightforward way, Tesla is listing this kind of maintenance as 'CAP X' or capital expenditure. Capital expenditures typically refer to investments in facilities or capacities in a business, not ongoing maintenance of a consumer product. So, the 'shorts' are suggesting that something weird is going on with Tesla's books.

In any event, after this back and forth, with Walt suggesting that the group buy some puts and go short, I started laughing. Tesla had come up a lot, and that seemed to particularly vex Jeff. In response to my laughter, the conversation in the group went in this direction: 
Jeff: I think it's very ironic that we want to short the day l'm throwing in the towel.

Brandon: We don't care. We do whatever you say. We're not out there picking options on vols. The stock is worth 100 bucks. Tony and I put 500 grand [US\$500,000] on it.

Jeff: We were going to buy puts.

Brandon: If you're going to pay 7,000 dollars on a put spread, Tony and I don't care.

Jeff: Look, this isn't just me, this is a conversation.

Brandon: Sure. But you feel the most strongly about Tesla.

Tony: Yeah, after the earnings came out last time, I could care less. Before that, I could have carried a short position.

Brandon: All this seems reasonable, particularly if we want to put 3, 4, 5 hundred grand on the line. I just stopped looking at 30 grand tomorrow. I'm way more angry about losing money with other positions. We know at the end of the year if Tesla trades at 400, we lose 600 thousand dollars. If Jeff feels that strongly...

Jeff: I don't want this to be shifted to me. If anything, you've been quoting vega.

Brandon: We just don't care. Are you going to bitch about it when the stock goes to 200, and we make no money?

Jeff: This should be a conversation among everyone. I don’t want in seven months...

Brandon: I don't understand why you're exhausted; this stock has been irrational for three years now.

Jeff: It doesn't move; it doesn't react.

Tony: Well, it hasn't for a while.

Jeff: In December it got rational.

Tony: It also dropped to 250 after fraud was exposed by the SEC.

Brandon: I fundamentally believe the stock is worth 100 bucks. Really, just don't look at it. You feel the most strongly of all of us.

Jeff: This has always been a conversation; it's not just my trade, not just my position. We made 400 grand on it in the first week of January. We should all talk about it.

Brandon: I just never seem to care.

Jeff: Do you want to be long, short, or flat? You don't care? He doesn't care.

Brandon: You obviously care.

Jeff: I'm totally exhausted by the name and by him [Musk]. I stopped following him and all those guys on twitter. It's just, I don't want it to be a distraction from the stuff we're doing.

Brandon: I think that's up to you. You're the most distracted.

Jeff: I'm not following it. 
Brandon: I don't understand what changed now. The stock hasn't reacted rationally to the news since 4-20 day. ${ }^{6}$

Jeff: I think it has. The reaction to the SEC fraud, that day, was not normal. Do you understand my point? Even if I ever had full accountability for this before, we should have a vote now.

Tony: I'm indifferent.

Jeff: If we've got three 'indifferents'...

Tony: Should we be trading it?

Jeff: It's been sitting. Rotting.

Tony: Does anyone want to trade it?

Jeff: It seems like it's on BATS [a financial exchange], with the scanner [the name for an algorithm used to find trading opportunities]. We can see what happens.

[At this point my field notes simply say, "Long discussion about whether they should be trading Tesla".]

Jeff just couldn't catch a break in this chat; everyone was resigned. I want to highlight, though, what bothered him, and those things are myriad: first, he has an overwhelming sense that the market is treating information irrationally. He doesn't really know who he is interacting with on the other end of trades or what logic they're operating by. We know, too, that this type of ignorance is endemic to electrified, automated, and speedy financial markets (Lange, 2016; Souleles, 2019b). For Jeff, it becomes an object of both speculation and acknowledged limitation.

Jeff is also bothered by Tesla's accounting practices. Since Tesla is a publicly traded company, it publishes financial reports at regular intervals. Specifically, he's skeptical of the way in which they're accounting for their ongoing maintenance. He's worried that, by burying the cost in CAP X, they're not accurately accounting for how expensive maintenance is. Moreover, there are specific supply chain problems with replacement parts. These sorts of questions get at how one might fundamentally analyze a company like Tesla. We know too that a lot of assumptions are built into the valuation analysis of companies (e.g., Souleles, 2019a) and that, often, fundamental analysts fail to beat chance stock picks (Leins, 2018). Yet these sorts of company analyses "become successful through the formulation of...forecasts as persuasive stories" (Leins, 2018: 10). Jeff is engaged in an act of deliberation and persuasion. He's telling a story about the future value of Tesla. Given his role as a market maker, this is the role that he's supposed to take - that of a critical analyst who can then make pricing decisions. It just so happens that Jeff's story is proven wrong again and again by the rise in the stock market price generally and Elon Musk's ongoing defiance of business gravity specifically.

Jeff also is keenly aware of the actions of the SEC, a government policy-making and regulatory agency, that, among other things, oversees the quarterly financial filings of all publicly traded companies and the ongoing operations of all American stock markets. Not only were they investigating Elon Musk for manipulating Tesla's stock price via his erroneous reporting of potential buyouts and its valuation, this was also playing out in public via statements and the federal courts. Holmes (2014) has pointed out that other government actors and central bankers have increasingly used public address as part of their efforts to affect people's behavior (see also Riles, 2018). Moreover, the traders at Tradeco saw the 
heavy and constant intervention of government actors in financial markets as leading to possible cascade effects across various financial instruments. It's easy to see the SEC's court battles with Elon Musk in a similar light: he publicly flouted long-standing norms against insider trading, so, they, in an equally public manner went after him to signal to other corporate actors that there is a cop walking the beat even if that cop is basically losing.

Towards the end of the conversation, Jeff makes use of 'the scanner' to see if there are trading opportunities for Tesla puts. The scanner is a computer program by which TradeCo mechanically identifies good trading opportunities according to how they are valuing particular stocks and who they think is trading against them. It shows up as a small, manipulable gridded window with plain text on a portion of their monitors. The interesting thing about the use of the scanner is not so much that it is being used but that it shows up in a relatively routine way. Recently, MacKenzie (2018) has suggested that there is a genuine moral dimension to the trading habits of high-frequency market makers: if you take quotes faster than others are able to, you are taking liquidity and doing something predatory. Conversely, if you generate liquidity, you are doing the market a solid by creating more trading opportunities for others. Jeff and Tradeco, observed to me that they basically didn't act aggressively in markets - they posted bids and made offers creating market liquidity. The scanner allows them to routinize this moral stance and carry on as liquidity-providing market makers.

\section{Let's own that debt payment}

We've seen how the Tradeco traders' essentially have one long conversation in which all sorts of things weave in and out. We've also seen that their deliberations on how to price stock or options have to do with multivariate weighing of different company features and the larger market environment - companies, stocks, other traders, and government actors. To simplify things a bit: (1) Jeff didn't quite know why other people on the market were trading Tesla the way they were; (2) had big concerns about the fundamental analysis of Tesla's business; (3) noted the public actions of government actors; (4) and ultimately was trying to weigh whether or not Tesla's price would come down to earth and be subject to the laws of the market that so harshly discipline mere mortal companies.

However, all this doesn't really help us understand why Tradeco would price Tesla options in any given way or how this pricing affects money flows. Rather we just see how they do it. For an actual decision one way or another, we have to return one last time to Jeff's long lonely conversation, and see how he and his traders weighed all these different factors and relationships to make a pricing decision. After that, l'll offer two reflections.

[This exchange directly follows my 'Long Tesla Discussion Bracket' that ended the last exchange]

Jeff: Really, this discussion shouldn't be confrontational.

Brandon: We're not confronting you. We just want to know what changed for you?

Jeff: I just want a conversation: yay or nay?

Tony: I've had no opinion the last five months about Tesla, ever since the third quarter when they said they made money. I'm a lot less certain this thing is going to zero given that they actually reported earnings. I think we want to make a bet that something is going to happen around the time that their debt payment is due. We probably want to have that down. 
Brandon: The way I feel is that I have no reason to argue against your position. Your stuff checks out. If you want to short 5,000, go ahead and short 5,000. If that's how we feel about it, well, if we lose a bunch of money, that happens.

Jeff: Let's talk more later.

Tony: I wouldn't mind having something on for the debt payment.

Jeff: We could also move it to options.

Brandon: The three-week-out-straddle is 15 bucks. The vol is telling us that nothing is going to happen. Maybe that's the trade. I don't know.

Tony: I feel like owning that debt payment.

[Jeff left for the pit. Silence descends.]

Ultimately, and almost by exhausted default, Jeff's team takes an intermediate position. Instead of constantly speculating that Tesla is going to go bust, right around the corner, they decide to take a bet on an options spread around the day of Tesla's upcoming debt payment. Tesla's volatility suggests that nothing is going to happen to the stock. So, they're going to short 5,000 stock and hope to make money.

Tesla's stock was generally down in the months following my first visit, on into the summer of 2019 , and took a dive (around US\$40) shortly after the bond payment came due on March 1. It's likely that Jeff and his group at Tradeco made money on their position, betting against Tesla (as Musk and others invested in Tesla lost money). Long-term, however, Tesla's irrepressible rise continued, reaching US $\$ 1,200$ per share in the Fall of 2021, presumably agitating Jeff still. So, here, then, is an example of the sort of vexed decision-making I had hoped to elucidate. Jeff and his team weighed: (1) their technological capabilities; (2) their fundamental analysis of Tesla; (3) the behavior of their unknowable market counterparties; (4) the government's public policy actions; and (5) their internal diversity of opinions to risk US $\$ 500,000$ betting against Tesla via their options pricing decisions.

What's interesting, academically at least, to all of this, is that you would not be able to explain Tradeco's pricing decision by relying only on the technology of automation and algorithms. The world the algos create is bigger than just that. The decision Jeff's team took subsumes and weighs a number of features about contemporary financial markets that add up to a sort of holistic though frustrating decision-making process.

Different market participants (brokers, pensions funds, etc.) would deliberate and express their market opinions according to the affordances and constraints of their specific nodal and functional points in market networks as well as to the relationships that those locations entail. Jeff and his team, too, were painfully aware that their sensibilities and market position put them in a position without much agency on markets. The weight of this minority position comes into sharper focus with a bit more reflection about who stands to benefit from rising Tesla prices.

Recall that the crux of the Jetski Friday joke and t-shirt was that the Fed was more interested in pumping up markets and helping retirement accounts than allowing for any sort of market-minded policing of bad economic actors (bad, at least in the mind of Jeff and his team). Linking market fortunes to retirement accounts had a further, nuanced significance for Tesla and many other publicly traded stocks. Often these stocks make up the largest appreciating assets individuals in the US carry with them into retirement, whether via formal, 
workplace-based pension funds or self-managed investment accounts. As of 11 November 2019, CNN Business reported that institutional investors (meaning retirement account managers like Vanguard and BlackRock among others) owned $51.49 \%$ of Tesla's stock. Moreover, specific pension funds, like the California Public Employees Retirement System and the New Jersey Division of Investment, both recently and modestly increased their holdings. All this, too, puts these institutional investors in a curious position since the largest single shareholder of Tesla stock is Elon Musk who owns about 20\%. In a funny way, then, the fortunes of individual retirees rise and fall according to the same fortunes as Tesla, the company, and Musk, the individual and CEO. Their financial destinies are connected.

Taking all this a step further, it's worth noting that cutting across every point in the traders' dialogue is a meta-conversation about Tesla's societal role. Jeff's team is frequently reflecting on Tesla while having other conversations, like those about retirement accounts and Jetskis. I think the reflective level of their conversation is important because it adds up to a sort of framing discourse, albeit one that is resigned and often frustrated. Once we see their conversations in this light, it invites us to consider some recent economic anthropology (e.g., Bear et al., 2015), which has argued that when analysing 'capitalist' processes, we should pay attention to the sorts of life-worlds those processes allow, and not just make a reductive 'economic' analysis. Here, Jeff and co. offer explicit testimony to that complex 'life-world': we hear value judgments about Elon Musk and the company he runs; we hear about other feckless or shrewd or inscrutable market actors, both political and financial; and we hear about retirees and how their wealth and livelihood is directly affected by Tesla being incorrectly valued (at least according to Jeff). We also hear how skeptical the traders are about the validity of a number of those life projects, and then see their resulting actions.

All that said, and key to Jeff's frustration, these opinions don't carry the day, nor do they move markets. Larger, barely scrutable forces are at work. So, Jeff feels estranged and unhappy with Elon Musk, Tesla, Inc, the markets that send Tesla's stock up, the politicians that cheer on those markets, and all the nameless, faceless market participants that Jeff is trading against, echoed in faint and fleeting indexical traces on his computer screen. In this particular instance, the traders don't decide to go all in and presume Tesla will fail. After all, they can't quite muster the conviction or enthusiasm for that dramatic a judgment; the accumulated evidence and opinion of the group is too ambivalent to support such a conclusion. As such, they take a middle path, and peg what ended up being a more reasonable bet. Put differently, Jeff and co. decided it was a bad idea to buy an electric car on this particular Jetski Friday.

\section{Acknowledgements}

This project received funding from the European Research Council (ERC) under the European Union's Horizon 2020 research and innovation programme (grant agreement no. 725706). Thanks are due to Leon Wansleben and several anonymous reviewers at Finance and Society; Elizabeth Ferry, Christian Borch, Bo Hee Min, Kristian Bondo Hansen, Pankaj Kumar, and Nicholas Skar-Gislinge; the Philosophy seminar at the Copenhagen Business School; and the traders at Tradeco for tolerating and critiquing drafts of this paper.

\section{Notes}

1. A reviewer helpfully noted that an earlier version of this observation of market forms of ignorance is present in Charles Smith's (1999) book, Success and Survival on Wall Street. 
2. Though some other traders maintained it was more widespread, to my knowledge only the central banks of Israel, Sweden, and Japan have acknowledged equity purchases as part of their balance sheets (Powell, 2019; Kennedy, 2019; see also Kremmidas, 2019).

3. Options traders' conversations are peppered with Greek symbols which come from the Black Scholes Merton equation and its derivatives, which are all used to price options. When they make a trade that is a bet on a specific aspect of an option's characteristics, they will often refer to the Greek letter associated with that characteristic. Collectively, these are referred to as 'The Greeks'. In this case, Vega refers to a stock's sensitivity to price changes given some change in a stock's volatility. Carrying '1200 Vega' means carrying some quantity of options that are reliant on a bet on Vega.

4. Again, Tesla made the payment, but dipped into its own cash reserves to do so.

5. 'Short players' here means investors who are betting on Tesla's stock going down.

6. Oh boy. In a series of tweets, Elon Musk said that he was going to take Tesla private and buy it out at US $\$ 420$ per share, which sent the stock soaring. This is a pot reference - either the time of day (4:20 PM) or the day of the year (20 April) when you're supposed to get high - 'four-twenty'. Musk picked 4-20, allegedly, because he had just 'gotten into' marijuana and thought his girlfriend, the pop-singer Grimes, would find it funny. Partially as a consequence, the SEC wanted to bar Musk from running a publicly traded company (Taylor, 2018).

\section{Appendix}

Table 1. Members of the options market-making group at Tradeco.

\begin{tabular}{|l|l|l|l|l|}
\hline Pseudonym & Age & Gender & Race/Ethnicity & Job role/Function \\
\hline Jeff Miller & 40 & M & White, Euro-American & Team leader \\
\hline Walt Bennett & 55 & M & White, Euro-American & Supervising partner \\
\hline Aaron Meyers & 23 & M & White, Euro-American & $\begin{array}{l}\text { Junior team member, coding, analytic work, } \\
\text { apprentice trading work }\end{array}$ \\
\hline Tony Ellis & 29 & M & White, Euro-American & $\begin{array}{l}\text { Options trader, monitoring group market-making } \\
\text { positions, occasional pit trading }\end{array}$ \\
\hline Brandon Price & 35 & M & Asian, Chinese-American & $\begin{array}{l}\text { Options trader, monitoring group market-making } \\
\text { positions }\end{array}$ \\
\hline Rob Ortiz & 40 & M & Latino, Mexican-American & Options trader, trading on yield curve spreads \\
\hline Lee Foster & 35 & M & White, Euro-American & Options trader, pit trader \\
\hline Kyle Hughes & 30 & M & Asian, Chinese-American & $\begin{array}{l}\text { Options trader, monitoring some market making } \\
\text { trading, programming }\end{array}$ \\
\hline Zach Bauer & 50 & M & White, Euro-American & \begin{tabular}{l} 
Chief Information Officer \\
\hline
\end{tabular}
\end{tabular}

\section{References}

Agha, A. (2000) Register. Journal of Linguistic Anthropology, 9(1-2): 216-19.

Agha, A. (2015) Voice, footing, enregisterment. Journal of Linguistic Anthropology, 15(1): 38-59.

Bear, L., Ho, K., Tsing, A. and Yanagisako, S. (2015) Gens: A feminist manifesto for the study of capitalism. Cultural Anthropology, 30 March. Available at: <https://culanth.org/fieldsights/652gens-a-feminist-manifesto-for-the-study-of-capitalism/>. Accessed 22 November 2021. 
Benanav, A. (2020) Automation and the End of Work. London: Verso.

Beunza, D. and Stark D. (2004). Tools of the trade: The socio-technology of arbitrage in a Wall Street trading room. Industrial and Corporate Change, 12(2): 369-400.

Beunza, D. (2019) Taking the Floor: Models, Morals, and Management in a Wall Street Trading Room. Princeton, NJ: Princeton University Press.

Bryan, D. and Rafferty, M. (2006) Capitalism with Derivatives: A Political Economy of Financial Derivatives, Capital and Class. New York: Palgrave Macmillan.

Buenza, D. and Stark, D. (2012) From dissonance to resonance: Cognitive interdependence in quantitative finance. Economy and Society, 45(2): 278-302.

Callon, M. (ed.) (1998) The Laws of the Market. Malden, MA: Blackwell.

Cetina, K.K. and Bruegger, U. (2002) Traders' engagement with markets. Theory, Culture \& Society, 19(5/6): 161-85.

Cetina, K.K. and Preda, A. (2007) The temporalization of financial markets: From network to flow. Theory, Culture \& Society, 24(7-8): 116-38.

Denzin, N. (1970) The Research Act. New Brunswick, NJ: Aldine Transaction.

Hansen, K.B. and Borch, C. (2021) The absorption and multiplication of uncertainty in machine learning-driven finance. The British Journal of Sociology, 72(4): 1015-29.

Harwell, D. (2019a) Tesla's Model Y is a car Elon Musk hopes will distract from everything else. The Washington Post, 15 March. A19.

Harwell, D. (2019b) SEC's fight with Musk over his tweets seems likely to go a few more rounds. The Washington Post, 20 March. A16.

Heath, C., Jirotka, M., Luff, P. and Hindmarsh, J. (1994) Unpacking collaboration: The interactional organization of trading in a city dealing room. Computer Supported Cooperative Work, 3(2): 14765.

Holmes, D. (2014) An Economy of Words: Communicative Imperatives in Central Banks. Chicago, IL: University of Chicago Press.

Hutchins, E. (1995) Cognition in the Wild. Cambridge, MA: MIT Press

Kennedy, S. (2019) Central banks boost holdings of equities beyond \$1 Trillion. Bloomberg, 11 June. Available at: <https://www.bloomberg.com/news/articles/2019-06-11/central-banks-boostholdings-of-equities-beyond-1-trillion/>. Accessed 20 September 2019.

Kremmidas, T. (2019) Central banks invest in equities as foreign exchange reserves swell. Canadian Business Journal, 14 August. Available at: <https://www.cbj.ca/ central_banks_invest_in_equities_as_foreign_exchange_reserves_sw/ $>$. Accessed 20 September 2019.

Kuiper, K. (1996) Smooth Talkers: The Linguistic Performance of Auctioneers and Sportscasters. Mahwah, NJ: L. Erlbaum Associates.

Lange, A.C. (2016) Organizational ignorance: an ethnography of high-frequency trading. Economy and Society, 45(2): 230-50.

Lange, A.C., Lenglet, M., Seyfert, R. (2019) On studying algorithms ethnographically: Making sense of objects of ignorance. Organization, 26(4): 598-617.

Leins, S. (2018) Stories of Capitalism: Inside the Role of Financial Analysts. Chicago, IL: University of Chicago Press.

MacKenzie, D. (2008) An Engine, Not a Camera: How Financial Models Shape Markets. Cambridge, MA: MIT Press

Mackenzie, D. (2018) Material signals: A historical sociology of high frequency trading. American Journal of Sociology, 123(6): 1635-83.

MacKenzie, D. (2019) Market devices and structural dependency: The origins and development of 'dark pools'. Finance and Society, 5(1): 1-19. 
MacKenzie, D., Beunza, D., Millo, Y. and Pardo-Guerra, J.P. (2012) Drilling through the allegheny mountains: Liquidity, materiality and high-frequency trading. Journal of Cultural Economy, 5(3): 279-96.

MacKenzie, D. and Pardo-Guerra, J.P. (2014) Insurgent capitalism: Island, bricolage and the re-making of finance. Economy and Society, 43(2): 153-82.

MacKenzie, D. (2021) Trading at the Speed of Light: How Ultrafast Algorithms are Transforming Financial Markets. Princeton, NJ: Princeton University Press.

Marx, K. (1978) Estranged labor. In: The Marx-Engels Reader. New York: Norton, 70-81.

McMillan, L.G. (2002) Options as a Strategic Investment. Fourth edition. New York: New York Institute of Finance.

Miyazaki, H. (2013) Arbitraging Japan: Dreams of Capitalism at the End of Finance. Berkeley: University of California Press.

Pardo-Guerra, J.P. (2019) Automating Finance: Infrastructures, Engineers, and the Making of Electronic Markets. Cambridge: Cambridge University Press.

Pitluck, A., Mattioli, F. and Souleles, D. (2018) Finance beyond function: Three casual explanations for financialization. Economic Anthropology, 5(2): 157-71.

Powell, J. (2019) The ECB buying equities: SNORE. Financial Times, 29 July. Available at: <https:// ftalphaville.ft.com/2019/07/29/1564403005000/The-ECB-buying-equities-SNORE>. Accessed 20 September 2019.

Riles, A. (2018) Financial Citizenship: Experts, Publics and The Politics of Central Banks. Ithaca, NY: Cornell University Press.

Smith, Charles (1999) Success and Survival on Wall Street: Understanding the Mind of the Market. Lanham, MD: Rowman and Littlefield.

Souleles, D. (2017) Don't mix Paxil, Viagra, and Xanax: What financiers' jokes say about inequality. Economic Anthropology, 4(1): 107-19

Souleles, D. (2018) How to study people who do not want to be studied: Practical reflections on studying up. PoLAR, 41(S1): 51-68.

Souleles, D. (2019a) Songs of Profit, Songs of Loss: Private Equity, Wealth, and Inequality. Lincoln: University of Nebraska Press.

Souleles, D. (2019b) The distribution of ignorance on financial markets. Economy and Society, 48(4): 510-31.

Souleles, D. (2020) Knotty financiers: A comparative take on finance, value, and inequality. Journal of Anthropological Archaeology, 59(SI): 101205.

Souleles, D. (n.d.) Woosh Goes the Market: Rage, Fun, and a Million Dollars a Day. Unpublished book manuscript.

Spradley, J.P. (1980) Participant Observation. Long Grove, IL: Waveland Press.

Taylor, K. (2018) The SEC alleges that Elon Musk's \$420 price point was a weed reference to amuse his girlfriend. Business Insider, 27 September. Available at: <https://nordic.businessinsider.com/ sec-says-elon-musks-420-price-point-was-a-weed-reference-2018-9? $r=U S \& I R=T />$. Accessed 5 April 2019.

Tesla. (2019) About Tesla. https://www.tesla.com/about. Accessed 20 March 2019.

Weiss, H. (2021) Elusive adulthood and surplus life-time in Spain. Critique of Anthropology, $10.1177 / 0308275 \times 211004717$.

Wigglesworth, R. (2019) Are markets somehow ‘broken'? Financial Times, 14 June. Available at: <https://www.ft.com/content/af043692-8d4c-11e9-a24d-b42f641eca37/>. Accessed 22 July 2019.

Zaloom, C. (2006) Out of the Pits: Traders and Technology from Chicago to London. Chicago, IL: University of Chicago Press. 